\title{
Is a Responsive Business \\ Also a Responsible Business?
}

\author{
Colin Higgins \\ Victoria University, Australia
}

\begin{abstract}
While much has been written about corporate responsibility, arguments for transformation in the business $\&$ society relationship prevail. In this paper, the dominant normative and business-case perspectives of corporate responsibility are examined in light of their assumptions regarding change. Both rely on modernist, firm-centred assumptions regarding management agency. Change in the business and society relationship may require closer attention being paid to processes of social norm formation.
\end{abstract}

\section{Keywords}

Corporate responsibility, change, assumptions, social norm formation.

\section{Introduction}

The social responsibility of business has interested researchers and practitioners for decades (Birch, 2001; Bradley, 1987; Carroll,1999; Clark, 1916; Crane, McWilliams, Matten, Moon, \& Diegel, 2008; van Oosterhout \& Heugens, 2008). Numerous perspectives about what business should do, and why, have developed (De Bakker, Groenewegen, \& Den Hond, 2005; Dentchev, 2009; Garriga \& Mele, 2004; Mele, 2008) and businesses routinely engage in a number of social and environmental practices (Maignan \& Ralston, 2002; McIntosh, Thomas, Leipziger, \& Coleman, 2003; van Oosterhout \& Heugens, 2008; Whitehouse, 2006).

Despite widespread uptake of 'socially responsible' activities by business, however, many concerns remain (Basu \& Palazzo, 2008; O’Dwyer, 2003). Daily newspapers reveal on-going issues of employee discrimination and exploitation, the privileging of profitability over local communities, inappropriate and often illegal environmental breaches, and questionable claims about product performance. Additionally, tensions surface regularly about business and its influence on the public policy process - not only in domestic situations like taxation and regulatory reform, but also on the international stage in terms of trade, democratic participation, and the exploitation of developing countries. The academic literature is replete with a regular recycling of concerns about business impacts, and the need to re-think the business and society relationship (Scherer \& Palazzo, 2007). Questions thus arise about corporate responsibility and whether its practice makes much difference to improving social wellbeing (van Oosterhout \& Heugens, 2008).

Part of the problem relates to poor consideration of organisational and social change. To date, most

Copyright (C) 2010 Victoria University. This document has been published as part of the Journal of Business Systems, Governance and Ethics in both online and print formats. Educational and non-profit institutions are granted a nonexclusive licence to utilise this document in whole or in part for personal or classroom use without fee, provided that correct attribution and citation are made and this copyright statement is reproduced. Any other usage is prohibited without the express permission of the publisher. emphasis in the CSR literature has been on describing and justifying the responsibilities that should be assumed by managers. If change is considered at all, most scholars rely on either (or some combination of) moral persuasion or business-case arguments to encourage more socially just or sustainable outcomes. These approaches reflect modernist assumptions about management rationality 
and agency (Jones, 1996) and overlook broader considerations about the processes of social and organisational change (O’Dwyer, 2003).

In this paper, I suggest that change in the business and society relationship rests on de-centering the business organisation, and focusing on processes of social norm formation. I argue that morality-based and business-case arguments are second-order drivers of business activity. In essence, business organisations can, and will, behave differently when social expectation mounts both subtle and direct pressures.

This paper is structured thus. In the next section, I provide an overview of the major threads in corporate responsibility thinking, and illustrate the poor consideration given to questions of change. I highlight the shortcomings of both morality-based arguments, and the flaws within business casethinking. I point out that business-case thinking dominates understandings about corporate responsibility, and the means to bring about change. I conclude the paper by calling for more research into social movements and drivers outside business organisations as a strategy for effecting change in the business and society relationship.

\section{Corporate Social Responsibility}

Notions of 'corporate responsibility' are usually traced to concerns about the power of business and undesirable corporate impacts observed during the 1950s and 1960s (Birch, 2001; Bowen, 1953; Carroll, 1999). Reflecting emerging social movements about the environment, employees, and consumers (Carroll, 1979), corporate responsibility posed challenges to prevailing ideology and also raised new ethical imperatives for managers (Carroll, 1999; Levitt, 1958). Books such as Selekman's 1959 Moral Philosophy for Management and Heald's 1957 paper Management's Responsibility to Society contributed to thinking that capitalism required "a profound metamorphosis" (Thurow, 1966, p. 326), that there were 'social limits to growth' (Hirsch, 1976), and that the individualism of market capitalism, the universal participation of democracy, and unequal distribution of income was unsustainable. From an ideological perspective, Rockefeller (1974) called for greater integration between business and society, and Brown (1979) argued that business needed to shift "from an organisation conscious of a single purpose (profit) to one conscious of a multiplicity of purpose (economic, social, psychological, educational, environmental, and even political") (p.20).

Research into corporate responsibility has since covered wide territory (Basu \& Palazzo, 2008). Reviews of the literature consider: its degree of idealism (Dentchev, 2009); its empirical and theoretical, qualitative or quantitative, normative or non-normative emphases (Lockett, Moon, \& Visser, 2006) in various countries (Egri \& Ralston, 2008) and whether it reflects instrumental, political, integrative and/or ethical concerns (Garriga \& Mele, 2004). Some have considered the extent to which CSR is progressing (De Bakker, et al., 2005) and evolving (Gerde \& Wokutch, 1998) or has evolved (Carroll, 1999; Frederick, 2008) as a field. Others highlight the environmental, social, and/or economic dimensions of CSR and its emphasis on stakeholders and with voluntariness (Dahlsrud, 2008). Despite much being said about 'what' a socially responsible business should do (or be), little careful attention has addressed how such changes can come about. In other words, most focus in CSR work has been on the 'what' and the 'why', but very little about the organisational 'how'.

Most contributions to CSR are positioned in contrast to the view articulated by Milton Friedman - that the only social responsibility of business is to maximise its profits (Friedman, 1970). While Friedman's argument is based (in part) on normative assertions regarding property rights, a fiduciary relationship between owners and managers, and utilitarian arguments about the distributive effects of wealth maximisation (Henderson, 2001); CSR theorists tend to draw on alternative normative frameworks. In particular, notions of justice, the rights of stakeholders, the duties of managers, and/or a social contract between business and society (Lockett, et al., 2006; Matten, Crane, \& Chapple, 2003; Scherer \& Palazzo, 2007; Windsor, 2006) specify expanded corporate responsibilities and managerial behaviours.

Stakeholder theory has been a particularly enduring and influential contribution (Mele, 2008). Stakeholder theory directs managers to treat organisational constituents 'fairly' in organisational deliberations (see also Phillips, 1997) and also with respect to organisational outcomes (Evan \& 
Freeman, 1993; Mele, 2008). Additionally, managers have an obligation to explain the principles that sit behind their decisions (Hosmer \& Kiewitz, 2005), and they should also incorporate ethical considerations into their decision-making (Swanson, 1999; 1995). Some argue that stakeholders have particular rights, and attempts have been made to codify the UN Declaration of Human Rights into specific management obligations (eg the UN Global Compact, the Global Sullivan Principles, and the SA8000 certification program). The rights of stakeholders, however, go beyond basic human (Gibson, 2000) or liberty rights (Lea, 2004). Most commonly, they're justified on the basis of Kantian ethics. Freeman (1984) suggested, for example, that " each stakeholder group has a right not to be treated as a means to some end" (p. 14, and see also Bowie, 1991; Donaldson \& Preston, 1995; Gibson, 2000; Hasnas, 1998). Others implore managers to engage with stakeholders to formulate corporate responsibilities. Phillips (1997), for example, draws on Habermas' discourse ethics to suggest that corporate responsibilities can be developed through dialogue with those affected (see also Scherer and Palazzo, 2007). Freeman (2002) and his colleagues (eg Phillips, 2003) extended Rawls' work to suggest that a 'thought experiment', under a 'veil of ignorance', could generate agreement on a minimum set of outcomes that morally bind social actors, including business (Evan \& Freeman, 1993; Scherer \& Palazzo, 2007).

Some corporate responsibilities arise out of the business and society relationship, rather than from obligations owed to specific groups and individuals. The social contract perspective, for example, assumes that an 'agreement' exists between business and the community (Anshen, 1970; Bowie, 1983; Crowther \& Rayman-Bacchus, 2004; Dahl, 1975; Den Uyl, 1984), much like that which justifies the existence of the state (see Hobbes, Locke, Rousseau in Donaldson, 1982). Accordingly, managers should serve the interests of society because of the benefits extended to it (eg use of public goods, limited liability) by the community (Donaldson, 1982; Donaldson \& Dunfee, 1994; Dunfee, 1991). Argandona (1998) draws on Aristotlean notions of 'participation' and argues that business has an obligation to contribute to the 'common good' - those societal conditions that are beneficial and fulfilling for everyone (see Erisksen \& Weigard, 2000). Early versions of 'corporate citizenship' were similar (Davis, 1973; Eilbert \& Parket, 1973; Mele, 2008) and emphasised 'good neighborliness' (Solomon, 1992). Current views about global corporate citizenship incorporate an obligation to respect (local) societal norms (Mele, 2008; Logsdon \& Wood, 2002; Wood \& Logsdon, 2001). Considerations of Inter- and intra-generational equity, as well as a broad obligation to ensuring current and future generations enjoy life-sustaining conditions, are reflected in notions of business and sustainable development (Bebbington, 2001; Dentchev, 2009; WCED, 1987). Ethical approaches to CSR are basically concerned about morally indifferent business conduct and promoting the social advantages of responsible management and expansive public policy (Windsor, 2006).

Many contributions to corporate responsibility, however, downplay normative arguments and/or attempt to integrate them with prevailing business practice. Despite CSR usually being positioned in contrast to Friedman (1970), not all contributions consistently or categorically reject his underlying ideology. Probably the most well developed integrative framework is corporate social performance (Gond \& Crane, 2009) in which ethical, legal and discretionary (social or philanthropic) responsibilities are aligned with economic obligations. First mooted by Carroll (1979) as an attempt to clear up confusion within the literature; corporate social performance also sought to ally criticisms that social responsibility ignored economic responsibilities. Carroll (1979) summarises the various responsibilities expected of business into four dimensions, and also captures different philosophies of responsiveness (ranging from reaction to pro-action). Wartick \& Cochrane (1985) reformulated Carroll's framework into a Principles - Processes - Policies framework, introducing the idea that corporate social performance involves aligning these different dimensions. Wood (1991) extended this work further and incorporated expectations that circulate at institutional, organisational and individual levels into the CSP model. She, additionally, suggested that stakeholder engagement, issues management and codes of ethics were important processes of social performance. When taken together all contribute to achieving robust and effective economic, social and environmental outcomes.

Similar ideas are reflected in most perspectives about corporate social responsibility, and businesscase and instrumental thinking has come to dominate CSR work (Windsor, 2001). Donaldson \& Preston (1995), for instance, review instrumental approaches to stakeholder theory - pointing out the 
increasing perspective that managers should engage with stakeholders to achieve corporate performance goals. Additionally, Birch (2001) argues that corporate citizenship rests on 'sustainable capitalism' and involves taking a systematic approach to identifying and managing social/environmental expectations to generate win-win opportunities. The social contract is said to ensure organisational legitimacy (Milne \& Patten, 2002; Suchman, 1995); respecting community expectations secures a social licence to operate that is necessary for generating superior long-term financial performance. Recent threads in understanding business and sustainable development are similar. Bebbington (2001), for example, demonstrates that sustainability is mostly reflected as 'good environmental management' and 'eco-efficiency' within business literatures, and Salzmann, IonescuSomers, \& Steger (2005) suggests that consideration of sustainability can generate a number of business benefits. Instrumental perspectives can be thought of as 'enlightened self-interest' (Keim, 1978) and, like corporate social performance, downplay conflict between economic and social/environmental outcomes, and assert that corporate responsibility largely equates to corporate social responsiveness (O'Dwyer, 2003; Spence, 2007; Windsor, 2001).

\section{CSR and Organisational Change}

Despite considerable developments about corporate responsibility, current arguments for CSR have changed little during the past 50 years (see Bowen, 1953; Heald, 1957; Selekman, 1959; Thurow, 1966; Rockefeller, 1974; Brown, 1979; and above) raising questions about its value for generating change. Andriof \& McIntosh (2001), for example, suggest that business needs to understand that everything it does "has some flow on effect either inside or outside the company... [and that corporate citizenship involves] a deeply held vision by corporate leaders that business can and should play a role [in society] beyond just making money" (p. 15). Additionally, current discussions about business and sustainable development point to transformational change - similar to arguments made in the 1950s. 'Strong' sustainability challenges the accumulation of wealth and consumption-based growth (Bebbington, 2001). At an organisational level, Tichy, McGill, \& St. Clair (1997) demand greater integration between business and society, and Welford (1997) calls for a conceptualisation of business, as a social institution, built upon stakeholder engagement and corporate democracy. 30 years ago Davis (1975) made similar suggestions. Business should, he argued: develop and maintain open and continuous relationships between itself and society, to enable it to provide an account of its activities and impacts, but also to keep up to date with social issues and concerns; it should seek to consider the full economic, social and environmental costs of producing its products and services, and reflect these in its pricing; and it must go beyond minimising harm, to fulfil a citizenship role by contributing to solving social problems and issues. What is significant is the commonality within these arguments and perspectives, and that the arguments have been so enduring.

One key issue is poor consideration of the processes of social and organisational change in CSR theorising. Arguments about stakeholder rights, distributive justice of organisational effects, and an obligation to participate in the resolution of social issues are not unreasonable. The case for expanded corporate responsibilities is well made, and soundly justified according to respected ethical theory (although see Scherer \& Palazzo, 2007, and below, for some criticisms). What is problematic are assumptions that if managers can be convinced about the 'right thing to do', or the business benefits of being socially responsible, they will voluntarily change their behaviour and transform their organisations. Such assumptions reflect modernist assumptions about management rationality and agency, and fail to comprehend the way change comes about, and is resisted, in organisational settings.

Normative CSR work relies on moral persuasion, particularly imploring managers to 'do the right thing'. Most scholars working in this area have sought to develop a universal, dispassionate and impartial set of corporate responsibilities (Scherer \& Palazzo, 2007) that can be implemented. The assumption is that if corporate responsibilities can be described and justified, managers will voluntarily direct their organisations toward more socially just and sustainable outcomes. Zenisek (1979), for instance, suggested in the late 1970s, that his model "indicate[s] the areas of managerial focus required... to achieve harmony between managerial attitudes and behaviour in relation to environmental demands" (p. 367). Freeman's (1984) description of stakeholder theory was to enable 
managers to "explore the logic of the concept in practical terms, ie in terms of how organisations can succeed in the current and future business environment" (p. 72). Donaldson \& Preston (1995) suggest stakeholder theory relates, primarily, to managerial decision-making. More recently, Dentchev's (2009) review of the normative and philosophical CSR literature found most of it was concerned with developing principles to "guide companies to promote 'social good' and to prevent 'social harm"" (p. 5) that can be "integrated in the organization, adopted as a reference for decision making, and shared by organizational members" (p. 5). Savage, Nix, Whitehead, \& Blair (1991) tried to "introduce practicing managers to the stakeholder concept to improve their ability to implement stakeholder management practices" (p. 77). Tellingly, considerable attention has been afforded to business ethics in management education (Gerde \& Wokutch, 1998), with the assumption being, presumably, to raise the consciousness of business students to enable them to behave ethically and responsibly in business situations. Some acknowledge that CSR challenges conventional business thinking, but contend that "all that is necessary [is] to show that such characteristics [of stakeholder rights] are the same as those giving rise to fundamental concepts of property rights" (p. 85). What Donaldson \& Preston (1995) (and others) overlook are whether managers, once convinced, will change their behaviour.

Some problems regarding change rest on the nature of normative theorizing. Assertions about rights, justice, and obligations are based on philosophical reasoning that is not easily digestible by managers. Normative obligations create puzzles for managers and contain few insights about managing tradeoffs (Windsor, 2006). Further, the monological character of Western ethical theory (Scherer \& Palazzo, 2007) denies the socially-constructed nature of values and expectations. Ethical assertions are theoretical statements deduced from logic and argumentation and, while they're possibly acceptable and almost certainly justifiable, there is nothing inherent in normative assertions that mean they will necessarily be actioned. Surveys of managers' attitudes and their understanding of corporate responsibility (including some of its radical elements) show they understand the issues, but this does not translate into fundamental change to the business and society relationship (O'Dwyer, 2003). The assumption that mangers will voluntarily change their organisations once convinced of 'the right thing to do' is highly problematic.

Integrated and instrumental CSR work takes a different approach, and attempts to convince managers that acting in a socially responsible way contributes to superior financial performance. The basic idea is that social problems can be turned in to profitable business opportunities (Drucker, 1984; Porter \& Kramer, 2006) and/or that business organisations can achieve superior financial returns by being 'socially responsible' (Burke \& Logsdon, 1996). Neither ideas are descriptively accurate in terms of managerial decision-making nor are they effective in bringing about enduring change in the business and society relationship.

The idea of turning social and environmental problems into profitable a business opportunity is seductive, but it assumes that all problems can be addressed this way, and that managers will pursue and maintain those opportunities over the long term. While some social/environmental problems do present business opportunities (eg recycling of waste), not all do (eg addressing labour inequality in developing countries). Only those issues for which a business model can be easily applied, and then only those that would/could outperform competing business opportunities, will be addressed (Stroup, Neubert, \& Anderson, 1987). What's more, treating social and environmental issues as a business opportunity requires that such issues continue to prevail, and continue to be attractive investment propositions. Business thus could, arguably, have an interest in social/environmental problems continuing, rather than being resolved or eliminated (Berman, Wicks, Kotha, \& Jones, 1999). Stakeholders tend only to be noticed when they exhibit characteristics of power, legitimacy and urgency (Mitchell, Agle, \& Wood, 1997), and similar conditions of issue salience may shape business' pursuit of such opportunities. Finally, pursuing corporate responsibility as a business opportunity only focuses on the outcomes of business, rather than business operations and the philosophy of business practice. Much community concern about business relates to fundamental aspects of employee relations, decision-making and trade-offs in everyday business behaviour. As a strategy for generating widespread change to business practice and the business and society relationship, the idea of social issues as profitable business opportunities is limited. 
Others maintain that social issues do not necessarily present profitable business opportunities, but business can achieve significant benefits from acting in a socially responsible way. Considerable effort has gone in to testing the social responsibility/financial performance relationship (Lockett, et al., 2006; Margolis \& Walsh, 2003; McWilliams \& Siegel, 2000; Windsor, 2001), but no clear consensus exists on whether (or what) socially responsible behaviour leads to positive financial outcomes. Not only are these studies characterised by inconsistencies in what is studied and measured, van Oosterhout \& Heugens (2008) point out it is difficult to assess whether a particular business initiative is an expression of its corporate responsibility or a relatively decoupled act of responsiveness. They suggest that a lot of what passes as corporate responsibility is simply the pursuit of legitimacy by adopting 'appropriate' structural, strategic, or symbolic features which signal compliance with the social system (see also (Bebbington, Higgins, \& Frame, 2009) rather than a morally motivated pursuit of responsibility (see also Windsor, 2006). Instrumental arguments thus lack descriptive validity. The relationship between social responsibility and business benefit may not exist, and if it does it fails to explain why all business organisations aren't socially responsible or why some are successful despite poor social, environmental and ethical performance (eg Enron, the current furore over the practices of the major banks in Australia).

Business-case and instrumental arguments basically represent little more than strategic management. That is, some companies attempt to achieve above-average returns by strategically differentiating (as per Porter, 1985) themselves according to social responsibility, ethics or sustainability. Using 'social responsibility' to position an organisation relative to competitors is, however, limited in its ability to generate industry wide change. Not only is differentiation vulnerable to changes in company strategy, but it is also likely to be abandoned if all organisations in an industry decide to become 'socially responsible'. The point of difference would be lost, and companies would pursue an alternative means of differentiation. Like other 'business case' arguments, strategic differentiation will also only generate selected corporate behaviours that are valued and recognised as different by customers. Arguably, community expectations of business behaviour go beyond those that can be marketed.

Instrumental and integrated approaches suffer from the basic flaw that assumes more 'business as usual' can solve the problems of 'business as usual'. Pursuing superior financial performance by engaging in some (selected) socially responsible activities represents little more than traditional shareholder and wealth creation perspectives about corporate responsibility (as per Friedman, 1971, and see Windsor, 2001, 2006). If corporate responsibility is concerned with effecting changes to dominant business ideology, refining business practice whilst maintaining the emphasis on free market ideology, voluntariness, natural liberty and freedom of contract (Windsor, 2006) will clearly fall short of community expectations. More damaging, perhaps, are the broader socio-structural implications of instrumental thinking and business case arguments. These perspectives have come to dominate theory and practice, even in light of the acknowledged limitations. Imbued within instrumental and business case thinking are metaphors of journeying, care, transparency and the 'triple bottom line', which all provide an appearance that the dilemmas between profits and principles have been solved (Livesey, 2002; Livesey \& Kearins, 2002; Markus Milne, Tregidga, \& Walton, 2009).

\section{Conclusion}

Corporate responsibility is, at its core, about change in the business and society relationship, but that central tenet is what is most lacking in CSR work. While considerable understandings have developed about obligations and rights, and a number of responsiveness methods have evolved, arguments for change in the business and society relationship prevail.

While some CSR scholars have started to explore multi-level approaches to change (Aguilera, Rupp, Williams, \& Ganapathi, 2007), the role of activist groups (den Hond \& de Bakker, 2007), and drivers in the institutional environment (Campbell, 2007; Jones, 1999; Marquis, Glynn, \& Davis, 2007); calls for a new discourse (Arevalo, 2009; Jones, 1996; Kuhn \& Deetz, 2008; Wry, 2009) have largely fallen on deaf ears. Part of the problem is that most CSR work focuses too much attention on the business entity. Change is assumed to rest on convincing managers to direct their organisations to new or different outcomes. Moral persuasion and business case arguments overlook important socio-structural influences on organisations and how they change. As van Oosterhout \& Heugens (2008) argue in their 
'much ado about nothing' piece, there is little in prevailing CSR work that isn't covered by more powerful and better developed conceptual schemes.

In order to effect change in the business and society relationship, it is necessary to de-centre the business organisation, and to consider drivers for change that exist outside the organisation. To do so, however, two considerations are important: it is necessary to consider the 'how' along with the 'what'. That is, CSR is firstly about change. Its origins and the continuing arguments point to fundamental change in the business and society relationship, and this needs to be considered alongside how change comes about. In order to effect meaningful change in the business and society relationship, it is necessary to reclaim both the political dimension of CSR, and to consider more broadly the processes of organisational and social change.

Despite the limitations of the business case, de-centering the business organisation does raise some new considerations for instrumental arguments. Some important potential does exist. The business case exhibits a degree of robustness as a response mechanism to external shifts and changes. Business does respond to social shifts. Most of what we currently observe regarding business and climate change, for example, could only have come about due to external social pressure. If appropriate social movements can be enhanced, developed and supported we can be assured of some responsiveness on the part of business.

\section{References}

Aguilera, R., Rupp, D., Williams, C., \& Ganapathi, J. (2007). Putting the S back in corporate social responsibility: A multilevel theory of social change in organizations. Academy of Management Review, 32(3), 836-863.

Andriof, J., \& McIntosh, M. (2001). Introduction. In J. Andriof \& M. McIntosh (Eds.), Perspectives on Corporate Citizenship (pp. 13-24). Sheffield: Greenleaf.

Anshen, M. (1970). Changing the social contract: A role for business. The Columbia Journal of World Business, 5(6).

Arevalo, J. (2009). Dimensions of corporate social responsibility: A time for a new discourse. World Review of Entrepreneurship, Management and Sustainable Development, 5(1), 4-25.

Argandona, A. (1998). The stakeholder theory and the common good. Journal of Business Ethics, 17(9/10), 1093-1102.

Basu, K., \& Palazzo, G. (2008). Corporate social responsibility: A process model of sensemaking. Academy of Management Review, 33(1), 122-136.

Bebbington, J. (2001). Sustainable development: A review of the international development, business and accounting literature. Accounting Forum, 25(2), 128-157.

Bebbington, J., Higgins, C., \& Frame, B. (2009). Initiating sustainable development reporting: Evidence from New Zealand. Accounting, Auditing and Accountability Journal, 22(4), 588-625.

Berman, S., Wicks, A., Kotha, S., \& Jones, T. (1999). Does stakeholder orientation matter? The relationship between stakeholder management models and firm financial performance. Academy of Management Journal, 42(5), 488-506.

Birch, D. (2001). Corporate citizenship: Rethinking business beyond corporate social responsibility. In J. Andriof \& M. McIntosh (Eds.), Perspectives on Corporate Citizenship (pp. 53-65). Sheffield: Greenleaf.

Bowen, H. R. (1953). Social responsibilities of the businessman. New York: New York University Press.

Bowie, N. (1991). New directions in corporate social responsibility. Business Horizons, 34(4), 56-65.

Bowie, N., E. (1983). Changing the rules. In T. Beauchamp \& N. Bowie (Eds.), Ethical theory and business (2nd ed., pp. 103-106). Englewood Cliffs, NJ: Prentice Hall.

Bradley, I. (1987). Enlightened entrepreneurs. Great Britain: The Bath Press.

Brown, C. (1979). Beyond the bottom line. New York: MacMillan.

Burke, L., \& Logsdon, J. M. (1996). How Corporate Social Responsibility Pays Off. Long Range Planning, 29(4), 495-502.

Campbell, J. (2007). Why would corporations behave in socially responsible ways? An institutional theory of corporate social responsibility. Academy of Management Review, 32(3), 946-967. 
Carroll, A. (1979). A three-dimensional model of corporate performance. Academy of Management Review, 4(4), 497-505.

Carroll, A., B. (1999). Corporate social responsibility: Evolution of a definitional construct. Business and Society, 38(3), 268-295.

Clark, J. M. (1916). The changing basis of economic responsibility. Journal of Political Economy, 24(3), 209-229.

Crane, A., McWilliams, A., Matten, D., Moon, J., \& Diegel, D. (2008). The corporate social responsibility agenda. In A. Crane, A. McWilliams, D. Matten, J. Moon \& D. Diegel (Eds.), The Oxford Handbook of Corporate Social Responsibility (pp. 3-15). Oxford, UK: Oxford University Press.

Crowther, D., \& Rayman-Bacchus, L. (2004). Introduction. In D. Drowther \& L. Rayman-Bacchus (Eds.), Perspectives on corporate responsibility (pp. 1-17). Aldershot, UK: Ashgate.

Dahl, R. (1975). A prelude to corporate reform. In R. Heilbroner \& P. London (Eds.), Corporate social policy (pp. 18-19). Reading, Mass.: Addison Wesley.

Dahlsrud, A. (2008). How corporate social responsibility is defined: An analysis of 37 definitions. Corporate social responsibility and environmental management, 15(1), 1-13.

Davis, K. (1973). The case for and against business assumption of social responsibilities. Academy of Management Journal, 16, 312-322.

Davis, K. (1975). Five propositions for social responsibility. Business Horizons, June, 19-24.

De Bakker, F., Groenewegen, P., \& Den Hond, F. (2005). A bibliometric analysis of 30 years of research and theory on corporate social responsibility and corporate social performance. Business \& Society, 44(3), 283-316.

den Hond, F., \& de Bakker, F. (2007). Ideologically motivated activism: How activist groups influence corporate social change activities. Academy of Management Review, 32(3), 901-924.

Den Uyl, D., J. (1984). The new crusaders: The corporate social responsibility debate. Bowling Green, Ohio: The Social Philosophy and Policy Centre: Bowling Green State University.

Dentchev, N. (2009). To what extent is Business and Society literature realistic? Business \& Society, 48(1), $10-38$.

Donaldson, T. (1982). Corporations and Morality. Englewood Cliffs: Prentice Hall.

Donaldson, T., \& Dunfee, T. (1994). Toward a unified conception of ethics: Integrative social contracts theory. Academy of Management Review, 19(2), 252-284.

Donaldson, T., \& Preston, L. (1995). The stakeholder theory of the corporation: Concepts, evidence, and implications. Academy of Management Review, 20(1), 65-91.

Drucker, P. (1984). The new meaning of corporate social responsibility. California Management Review, 26(2), 53-63.

Dunfee, T. (1991). Business ethics and extant social contracts. Business Ethics Quarterly, 1(1), 23-51.

Egri, C., \& Ralston, D. (2008). corporate responsibility: A review of international management research. Journal of International Management, 14(4), 319-339.

Eilbert, H., \& Parket, I. (1973). The current status of corporate social responsibility. Business Horizons, 16(4), 5-14.

Erisksen, E., \& Weigard, J. (2000). The end of citizenship? In C. McKinnon \& I. Hampsher-Monk (Eds.), The demands of citizenship (pp. 13-24). London: Continuum.

Evan, W., \& Freeman, R. E. (1993). A stakeholder theory of the modern corporation: Kantian Capitalism. In T. Beauchamp \& N. Bowie (Eds.), Ethical theory and business (4th ed.). Upple Saddle River, NJ: Prentice Hall.

Frederick, W. (2008). Corporate social responsibility: Deep roots, flourishing growth, promising future. In A. Crane, A. McWilliams, D. Matten, J. Moon \& D. Siegel (Eds.), The Oxford Handbook of Corporate Social Responsibility (pp. 522-531). Oxford, UK: Oxford University Press.

Freeman, R. E. (1984). Strategic management: A stakeholder approach. London: Pitman.

Freeman, R. E. (2002). Stakeholder theory. In L. Hartman (Ed.), Perspectives in business ethics (pp. 171-181). Boston: McGraw-Hill.

Friedman, M. (1970). The social responsibility of business is to maximise its profits. New York Times Magazine, September 13, 33. 
Garriga, E., \& Mele, D. (2004). Corporate social responsibility theories: Mapping the territory. Journal of Business Ethics, 53(1/2), 51-71.

Gerde, V., \& Wokutch, R. (1998). 25 years and going strong: A content analysis of the first 25 years of the Social Issues in Management Division proceedings. Business \& Society, 37(4), 414-446.

Gibson, K. (2000). The moral basis of stakeholder theory. Journal of Business Ethics, 26(3), 245-257.

Gond, J.-P., \& Crane, A. (2009). Corporate social performance disoriented: Saving the lost paradigm. Business \& Society, 48(3), 446-507.

Hasnas, J. (1998). The normative theories of business ethics: A guide for the perplexed. Business Ethics Quarterly, 8(1), 19-42.

Heald, M. (1957). Management's responsibility to society: The growth of an idea. Business History Review, 31(4), 375-384.

Henderson, D. (2001). Misguided virtue: False notions of corporate social responsibility. Wellington: NZ Business Roundtable.

Hirsch, F. (1976). Social limits to growth. Cambridge, Massachusetts: Harvard University Press.

Hosmer, L., \& Kiewitz, C. (2005). Organizational justice: A behavioral science concept with critical implications for business ethics and stakeholder theory. Business Ethics Quarterly, 15(1), 67-91.

Jones, M. (1996). Missing the forest for the trees. Business and Society, 35(1), 7-41.

Jones, M. (1999). The institutional determinants of social responsibility. Journal of Business Ethics, 20(2), 163-179.

Keim, G. (1978). Corporate social responsibility: An assessment of the enlightened self-interest model. Academy of Management Review, 3(1), 32-40.

Kuhn, T., \& Deetz, S. (2008). Critical theory and corporate social responsibility: Can/should we get beyond cynical reasoning? In A. Crane, A. McWilliams, D. Matten, J. Moon \& D. Siegel (Eds.), The Oxford Handbook of Corporate Social Responsibility (pp. 173-196). Oxford, UK: Oxford University Press.

Lea, D. (2004). The imperfect nature of corporate responsibilities to stakeholders. Business Ethics Quarterly, 14(2), 201-217.

Levitt, T. (1958). The dangers of social responsibility. Harvard Business Review, 36(5), 41-50.

Livesey, S. (2002). The discourse of the middle ground: Citizen Shell commits to sustainable development. Management Communication Quarterly, 15(3), 313-349.

Livesey, S., \& Kearins, K. (2002). Transparent and Caring Corporations? - A Study of Sustainability Reports by the Body Shop and Royal Dutch/Shell. Organization \& Environment, 15(3), 233-258.

Lockett, A., Moon, J., \& Visser, W. (2006). Corporate social responsibility in Management research: Focus, nature, salience and sources of influence. Journal of Management Studies, 43(1), 115-136.

Logsdon, J. M., \& Wood, D. J. (2002). Business Citizenship: From Domestic to Global Level of Analysis. Business Ethics Quarterly, 12(2), 155-187.

Maignan, I., \& Ralston, D. (2002). Corporate social responsibility in Europe and the US: Insights from businesses' self-presentations. Journal of International Business Studies, 33(3), 497-515.

Marquis, C., Glynn, M., \& Davis, G. (2007). Community isomorphism and corporate social action. Academy of Management Review, 32(3), 925-945.

McIntosh, M., Thomas, R., Leipziger, D., \& Coleman, G. (2003). Living corporate citizenship: Strategic routes to socially responsible business. London: FT and Prentice Hall.

Mele, D. (2008). Corporate social responsibility theories. In A. Crane, A. McWilliams, D. Matten, J. Moon \& D. Siegel (Eds.), The Oxford Handbook of Corporate Social Responsibility (pp. 47-82). Oxford, UK: Oxford University Press.

Milne, M., \& Patten, D. (2002). Securing organisational legitimacy: An experimental decision case examining the impact of environmental disclosures. Accounting, Auditing and Accountability Journal, 15(3), 372-405.

Milne, M., Tregidga, H., \& Walton, S. (2009). Words not actions! The ideological role of sustainable development reporting. Accounting, Auditing and Accountability Journal, 22(8), 1211-1257.

Mitchell, R., Agle, B., \& Wood, D. (1997). Toward a theory of stakeholder identification and salience: Defining the principle of who and what really counts. Academy of Management Review, 22(4), 853-886.

O'Dwyer, B. (2003). Conceptions of corporate social responsibility: The nature of managerial capture. Accounting, Auditing and Accountability, 16(4), 523-557. 
Phillips, R. (1997). Stakeholder theory and a principle of fairness. Business Ethics Quarterly, 7(1), 5166.

Phillips, R. (2003). Stakeholder theory and organizational ethics. San Francisco: Berrett-Koehler.

Porter, M. (1985). Competitive advantage: Creating and sustaining superior performance. Lonond: Collier Macmillan.

Porter, M., \& Kramer, M. (2006). Strategy and society: The link between competitive advantage and corporate social responsibility. Harvard Business Review, 84(12), 78-92.

Rockefeller, D. (1974). Essential quest for the middle way. In L. Silk (Ed.), Capitalism: The moving target. New York: New York Times Book Company.

Salzmann, O., Ionescu-Somers, A., \& Steger, U. (2005). The business case for corporate sustainability. European Management Journal, 23(1), 27-36.

Savage, G., Nix, T., Whitehead, C., \& Blair, J. (1991). Strategies for managing organizational stakeholders. Academy of Management Executive, 5(2), 61-75.

Scherer, A. G., \& Palazzo, G. (2007). Toward a political conception of corporate responsibility: Business and Society seen from a Habermasian perspective. Academy of Management Review, 32(4), 1096-1120.

Selekman, B. (1959). A moral philosophy for business. New York: McGraw-Hill.

Solomon, R. (1992). Ethics and excellence. New York: Oxford University Press.

Spence, C. (2007). Social and environmental reporting and hegemonic discourse. Accounting, Auditing and Accountability, 20(6), 855-882.

Stroup, M., Neubert, R., \& Anderson, J. (1987). Doing good, doing better: Two views of social responsibility. Business Horizons, 30(2), 22-25.

Suchman, M. (1995). Managing legitimacy: Strategic and institutional approaches. Academy of Management Review, 20(3), 571-610.

Swanson, D. (1999). Toward an integrative theory of business and society: A research strategy for corporate social performance. Academy of Management Review, July.

Swanson, D. L. (1995). Addressing a theoretical problem by reorienting the corporate social performance model. Academy of Management Review, 20(1), 43-64.

Thurow, L. (1966). The future of capitalism: How today's economic forces shape tomorrow's world. St Leonards, Australia: Allen \& Unwin.

Tichy, N., McGill, R., \& St. Clair, L. (Eds.). (1997). Corporate global citizenship: Doing business in the public eye. San Francisco: New Lexington Press.

van Oosterhout, J., \& Heugens, P. (2008). Much ado about nothing: A conceptual critique of corporate social responsibility. In A. Crane, A. McWilliams, D. Matten, J. Moon \& D. Siegel (Eds.), The oxford handbook of corporate social responsibility (pp. 197-223). Oxford: Oxford University Press.

Wartick, S., L, \& Cochrane, P., L. (1985). The evolution of the corporate social performance model. Academy of Management Review, 10(4), 758-769.

WCED, W. C. o. E. a. D. (1987). Our Common Future: . Oxford, UK: Oxford University Press.

Whitehouse, L. (2006). Corporate social responsibility: Views from the frontline. Journal of Business Ethics, 63(3), 279-296.

Windsor, D. (2001). The future of corporate social responsibility. The International Journal of Organizational Analysis, 9(3), 225-256.

Wood, D. (1991). Corporate social performance revisited. Academy of Management Review, 16(4), 691-718.

Wood, D., \& Logsdon, J. (2001). Theorizing business citizenship: From individuals to organizations. In J. Andriof \& M. McIntosh (Eds.), Perspectives on corporate citizenship (pp. 83-103). Sheffield: Greenleaf.

Wry, T. (2009). Does business and society scholarship matter to society? Pursuing a normative agenda with critical realism and neoinstitutional theory. Journal of Business Ethics.

Zenisek, T. (1979). Corporate social responsibility: A conceputalisation based on the organizational literature. Academy of Management Review, 4(3), 359-368. 